УДК 796.075.6

Сергій Гапоненко,

магістр, аспірант Кам'янець-Подільського Національного університету імені Івана Огієнка,

ID ORCID 0000-0001-7839-3869

DOI: $10.33099 / 2617-1775 / 2021-01 / 79-87$

\title{
ФОРМУВАННЯ УПРАВЛІНСЬКОЇ КОМПЕТЕНТНОСТІ МАЙБУТНІХ УЧИТЕЛІВ ФІЗИЧНОЇ КУЛЬТУРИ
}

У статті досліджуються поняття «педагогічні умови формування», «управлінська компетентність фахівців фізичної культури», а також з'ясовується сучасний стан їх сформованості. Проаналізовано і з'ясовано, щзо педагогічні умови формування - ие необхідні i достатні обставини підготовки, щзо забезпечують кінщеву мету. Аналіз наукових праць фахівиів дозволяє зробити висновок, що майбутня діяльність фахівия фізичної культури $i$ спорту, а фактично і управлінська компетентність передбачає, щуо під час професійної підготовки ми повинні ї̈ сформувати, щэо дозволить більш ефективно використовувати творчий, фізичний та інтелектуальний потенціал в теперішніх умовах праці, виконуючи професійні функиії на фоні високого рівня ділових $i$ особистісних якостей, в керуванні прочесами та людьми.

Ключові слова: педагогічні умови формування, управлінська компетентність фахівців фізичної культури.

Постановка проблеми. Глобальні зміни, що відбуваються в світі та Україні зокрема, потребують адаптації сучасного суспільства до швидкоплинності процесів у всіх сферах людської діяльності. Натомість, система вищої освіти - це саме та гнучка, динамічна складова, що може значно полегшити можливість комунікації сучасної людини в соціумі. 3 цього приводу стратегія державної кадрової політики на 2012-2022 роки передбачає забезпечення всіх сфер життєдіяльності держави кваліфікованими кадрами, необхідними для реалізації національних інтересів у контексті розвитку України як демократичної, соціальної держави 3 розвинутою ринковою економікою.

Аналіз останніх досліджень і публікацій. Світова наукова спільнота не стоїть осторонь цих процесів. В інформаційних джерелах знаходимо безліч наукових праць, що присвячені розв'язанню існуючих проблем. Так, проблему формування професійної компетентності вивчали Н. Волкова, Т. Волобуєва, Б. Гершунський, I. Зимня, В. Кремінь, Л. Майборода, В. Петрук, Дж. Равен, Ю. Татур, О. Торічний, А. Хуторський та багато інших. Основи професійної підготовки фахівців у ВВН3 розроблено О. Барабанщиковим, І. Біжаном, М. Нещадимом, В. Ягуповим та багатьма іншими. У професійній педагогіці аналізуються й обгрунтовуються проблеми професійної підготовки фахівців до здійснення управлінської діяльності науковцями: О. Бойком, I. Зязюном, В. Масловим, О. Романовським, В. Свистун, Р. Торчевським, В. Шемчук та ін. Крім цього розв'язуються основні проблеми менеджменту освіти М. Армстронгом， Л. Глінчуком，А. Грушевою， В. Данюком， Ю. Дубревським, 
Г. Сльниковим, С. Калашніковим, Ю. Коваленком, В. Масловим, М. Мішенко, В. Петюхом, В. Пікельною, В. Жигірь, В. Ягодніковою та інші.

Результати аналізу наукових робіт вказують на активний пошук шляхів удосконалення управлінської компетентності керівника взагалі. Разом з цим, не виявлено таких робіт, які б досліджували саме педагогічні умови формування управлінської компетентності майбутніх учителів фізичної культури.

Метою статті є психолого-педагогічний аналіз та обгрунтування понять «педагогічні умови формування», «управлінська компетентність фахівців фізичної культури», а також з'ясування сучасного стану їх сформованості.

Виклад основного матеріалу. Фізичне виховання громадян пов'язано, насамперед, 3 особистістю учителя фізичної культури, його професійними знаннями, педагогічною майстерністю, тактом, толерантністю, іншими особистими комунікативними якостями, а взагалі - професійною компетентністю. Адже вчитель фізичної культури - це первинна ланка для більшості громадян, коли вони в ранньому віці (дитячий садочок, школа, спортивна секція) стикаються з фахівцем фізичної культури. Тому він повинен бути професіоналом, який спроможний координувати дії щодо плану роботи школи 3 питань фізичного виховання, спорту, реакреації й туризму, організації роботи учнів на уроках фізичної культури та позаурочних заняттях, взаємодії 3 педагогічним колективом, батьками у створенні оптимальних умов для фізичного виховання й ведення здорового способу життя учнями.

Стратегія модернізації освіти України передбачає, що в основу оновленої освіти будуть покладені «компетентності фахівця», про які ми постійно говоримо і формування яких здійснюється завдяки компетентнісному підходу. Сам компетентнісний підхід, за твердженням науковців, означає поступову переорієнтацію домінуючої освітньої парадигми з переважаючою трансляцією знань, формуванням навичок на створення умов для опанування комплексу компетенцій [1, с. 138].

Однією з умов компетентністного навчання вчені вважають використання низки педагогічних умов, що сприятимуть підготовці фахівця у відповідній галузі. Для цього засвоюються не готові знання, а формуються вміння, необхідні для практичного вирішення конкретних завдань [2, с. 2-6].

Отже, питання ефективності педагогічного процесу тісно перетинаються з виконанням певних освітніх умов, а наукова спільнота не стоїть осторонь цієї проблеми. Спробуємо у подальшому розібратися з цією дефініцією.

За логікою нашого дослідження звернемось до першоджерел. Так, академічний тлумачний словник української мови трактує умову наступним чином: «Взаємна усна чи письмова домовленість про що-небудь; угода, договір» [3]. Інший великий тлумачний словник сучасної української мови це поняття подає так: «1. Взаємна усна чи письмова домовленість про що-небудь; угода, договір. 2. Вимога, пропозиція, що висуваються однією зі сторін, які домовляються про що-небудь, а також при укладанні угоди, договору. 3. Необхідна обставина, яка уможливлює здійснення, створення, утворення чого-небудь або сприяє чомусь. 4. Обставини, особливості реальної дійсності, за яких відбувається або здійснюється що-небудь. 5. Правила, які існують або 
встановлені в тій чи іншій галузі життя, діяльності, які забезпечують нормальну роботу чого-небудь. Правила, вимоги, виконання яких забезпечує що-небудь. 6. Сукупність даних, положення, що лежать в основі чогонебудь...» [4, с. 1297]. На наш погляд найбільш змістовно трактовка цієї дефініції подана В. Бусселом у останньому словнику.

3'ясуємо ще, як це поняття вчені трактують у наукових колах та своїх дослідженнях. Так, Г. Гапоненко, у своїх наукових дослідженнях, визначаючи педагогічні умови формування професійної компетентності водолазівпідривників, зазначав, що їх розробка вимагає підвищення вимог до самих результатів, які раніше формулювалися через такі поняття, як знання, уміння, навички. Тепер цей перелік вважають недостатнім, його доповнюють набором професійних компетентностей, які фактично характеризують різноманітну реалізаційну здатність фахівця... [5, с. 73].

Дослідники педагогічних умов розуміють їх як послідовність фахових дій, спрямованих на досягнення певного соціально-педагогічного ефекту, на соціалізацію учасників освітньо-виховного процесу. $\mathcal{C}$ наукова позиція, де під терміном «педагогічна умова» вважають обставини, що сприяють розвитку або, навпаки, гальмуванню навчально-виховного процесу та визначають їх як комплекс засобів, наявних у навчального закладу для ефективного здійснення навчально-виховного процесу. Ми погоджуємося з науковцями, які спеціально визначають термін «педагогічна умова» як певну обставину чи обстановку, яка так чи інакше впливає на творення, формування та розвиток педагогічних явищ, процесів, систем, якостей особистості, тощо.

Ми можемо і надалі проводити аналіз наукових досліджень в цьому напрямку, але нам зрозуміло, що вчені схиляються до думки, а ми робимо висновок, що навчально-виховний процес підготовки фахівців залежить від умов, в яких він відбувається. На наш погляд, педагогічні умови формування це необхідні і достатні обставини підготовки, щьо забезпечують кінщеву мету (підготовку фахівия певної спеціальності).

Тепер 3'ясуємо, що означає термін «управлінська компетентність фахівців фізичної культури». Досить влучне висловлювання про управління як процес, на нашу думку, висловив I. Міщенко. Він зазначав, що це сукупність дій людини, яка забезпечує досягнення бажаного результату - кінцевої мети. [6].

Академічний тлумачний словник української мови трактує термін управління так: «Дія за значенням управляти або керувати» [3]. Інший великий тлумачний словник сучасної української мови це поняття подає так: «1. Дія за значенням управляти. 2. Виконувати, завершувати якусь справу, надати комунебудь належного вигляду, задовольняти його потреби, доводити до ладу [4, с. 1511]. Публічний електронний словник української мови трактує термін «управляти» 1. Спрямовувати діяльність, роботу кого-, чого-небудь; бути на чолі когось, чогось; керувати [7, с. 1511].

3'ясуємо думки наукової спільноти 3 цього приводу. У вітчизняній і зарубіжній науці розроблено теоретико-методичне підгрунтя для розв'язання зазначеної проблеми. Так, теоретичні й методичні засади формування 
професійної компетентності фахівця в системі вищої освіти висвітлено в працях О. Акімова, В. Байденко, Н. Бібік, В. Безпалько, С. Гончаренко, І. Срмакова, І. Зимньої，А. Коломієць， В. Кременя， Н. Кузьміної， В. Лозової，О.Пометун, М. Степка, А. Хуторського, В. Ягупова, Дж. Равена, В. Хутмахера та багатьох інших. Теоретичні й практичні основи формування професійної компетентності вчителя фізичної культури досліджено в працях С. Глазунова, М. Віленьського, О. Дубогай, Ю Железняк, Л. Іващенко, Л. Лубишевої, Т. Круцевіч, А. Матвєєва, В. Платонова, Л. Сущенко, Б. Шияна та багатьох інших.

Аналіз наукових праць вище зазначених і багатьох інших фахівців дозволяє зробити висновок, що майбутня діяльність фахівия фізичної культури $i$ спорту (далі - ФКіС), а фактично $i$ управлінська компетентність передбачає, щзо під час професійної підготовки ми повинні ї̈ сформувати, щяо дозволить більш ефективно використовувати творчий, фізичний та інтелектуальний потенціал в теперішніх умовах прачі, виконуючи професійні функиії на фоні високого рівня ділових і особистісних якостей, в керуванні проиесами та людьми.

В своїй роботі В. Криштанович зробив висновок, що формування управлінської компетентності майбутніх фахівців фізичної культури і спорту $\epsilon$ тривалим процесом, який спрямовується на вдосконалення змісту, методів, засобів та форм їх навчання, що сприятиме формуванню комплексу ключових компетенцій, які необхідні для успішного виконання основних видів їхньої майбутньої управлінської діяльності [8, с. 122]. Як стверджував Ю. Дубревський, управлінська компетентність майбутнього викладача фізичної культури розглядається як інтегральна якість особистості, яка дозволяє керівнику у найбільш ефективний спосіб здійснювати свою діяльність, а також саморозвиток і самовдосконалення [9, с. 92].

Ми погоджуємося з думками вчених і рахуємо, що ефективність будь якої діяльності буде залежати від професіоналізму фахівця, тобто від його професійної компетентності як одного з найголовніших факторів професійної діяльності. Професійна діяльність будь-якого фахівця, незалежно від роду його професії, потребує постійного процесу підвищення професійної компетентності, саморозвитку, самовдосконалення. Разом з цим ми розуміємо, що компетентність фахівця ФКіС напряму буде залежати від результату його підготовки і виховання з урахуванням сукупних особистісних якостей людини.

В наукових колах терміни «компетенція» та «компетентність» за різними думками і твердженнями або використовують як синоніми або, як ми зазначили вище, виокремлюють якусь компетенцію та при цьому вважають її складовою загальної або професійної компетентності. Це як об'єкт і предмет дослідження, де об'єкт це стале, загальне, тобто компетентність, а предмет, відповідно, часткове - компетенція. Ми розуміємо, що мають право на існування різні наукові позиції, але тут і далі термін «компетенція» ми будемо розглядати як цеглини загального будинку, тобто складові частини загальної професійної компетентності фахівця.

За логікою нашого науково дослідження 3'ясуємо складові поняття «управлінська компетентність фахівця ФКіС», а також який зміст науковці 
вкладають в цю дефініцію і розберемо сучасний стан іï сформованості. Отже, управлінська компетентність майбутніх фахівців фізичної культури і спорту $\epsilon$ складним багатокомпонентним поняттям, як наголошував С. Криштанович. Вона характеризується такими науковими підходами: соціокультурним, діяльнісним, комунікативним, професійним, контекстно-інформаційним та психологічним. Проведений аналіз дозволив науковцю виділити ключові компетентності, до яких він відніс: соціально-особистісну, особистісноіндивідуальну, освітню, аналітичну, оцінно-контрольну, економічну, соціальну, психологічну, інформаційну, комунікативну. Вчений зазначав, що формування управлінської компетентності $є$ тривалим процесом і що фахівець ФКіС повинен нею не тільки володіти, а й вміти застосовувати [8, с. 120].

3 наукових позицій Ю. Войнар, Д. Наварецький, І. Глазирін зазначали, що управлінська компетентність фахівця галузі фізичного виховання і спорту розглядається як інтегрована професійно-особистісна характеристика у програмі навчальних закладів, яка повинна забезпечувати ефективний рівень їх професійної діяльності та відображати рівень сформованості професійної компетентності, що визначаються сукупністю мотиваційних i ціннісних установок, зумовлених необхідним обсягом знань і вмінь, рівнем професійної майстерності та досвідом роботи в обраній сфері діяльності [10, с. 124]. У роботі про педагогічні умови розвитку управлінського мислення В. Шемчук, акцентує увагу на точності та безпомилковості, мобільності і гнучкості, оперативності й конкретності, комплексності та системності мислення військового керівника [11].

Ю. Дубревський наголошував, що не зменшуючи значення напрацювань в педагогіці, у самому фізичному вихованні і спорті, виявлено відсутність єдиного погляду науковців щодо формування управлінської компетентності майбутніх фахівців фізичного виховання і спорту [9].

Ми погоджуємось 3 думкою цього та інших вчених і можемо доповнити їх висловлювання тим, що дослідження саме педагогічних умов формування управлінської компетентності у фахівців ФВіС в науковій літературі не виявлено взагалі. Тому вважаємо, що дослідження цього питання $\epsilon$ перспективним і заслуговує на увагу.

Розглянувши роботи цих та багатьох інших науковців, зробимо висновок, що управлінська компетентність фахівців фізичної культури - це інтегральний показник, щчо включає в себе: володіння сучасними педагогічними методиками $i$ технологіями; комунікативність у поєднанні $з$ творчопрогностичним мисленням; всебічна розвиненість; здатність до аналізу, узагальнення і впровадження передового сучасного зарубіжного, вітчизняного и історичного фізкультурного досвіду; оволодіння якостями, щзо формують системність мислення, бистроту реакиії на виникаючу проблему та прийняття рімення для ї̈ усунення або ліквідації наслідків; уміння мотивувати тих, з ким проводяться заняття, тренування до активізащії їх спортивної діяльності; уміння саморозвиватись, самовдосконалюватись.

Для теоретичного обгрунтування та експериментальної перевірки цілей, поняття, змісту та сучасного стану сформованості управлінської 
компетентності фахівців фізичної культури ми з'ясували реальний стан іiі сформованості та виявили основні проблеми і тенденції розвитку. Дослідження провели у двох вищих навчальних закладах: Кам'янець-Подільському Національному університеті імені Івана Огієнка (37 осіб), Національному університеті фізичного виховання і спорту України (53 особи). До опитування залучили студентів четвертого курсу навчання, а в якості експертів - науковопедагогічних працівників кафедр, що здійснюють підготовку фахівців ФКіС у цих навчальних закладах відповідно 4 та 6 осіб. Усього було залучено 90 студентів та 10 експертів. Для з'ясування сучасного стану сформованості управлінської компетентності майбутніх учителів фізичної культури студентам i експертам запропонували визначити ступінь їх задоволеності рівнем іï сформованості, а визначення здійснити за такими критеріями: не задоволені, опосередковано задоволені, максимально задоволені. Результати опитування були опрацьовані, а висновки подано в табл. 1.

Результати опитування студентів та науковців

\begin{tabular}{|l|c|l|c|l|}
\hline \multirow{2}{*}{ Рівень задоволеності } & \multicolumn{2}{|c|}{ Майбутні фахівці ФКіС } & \multicolumn{2}{|c|}{ Експерти } \\
\cline { 2 - 5 } & $\begin{array}{l}\text { Кількість } \\
\text { опитаних } \\
\text { студентів }\end{array}$ & $\%$ & $\begin{array}{l}\text { Кількість } \\
\text { опитаних } \\
\text { експертів }\end{array}$ & $\%$ \\
\hline Максимально задоволений & 8 & 8,88 & 1 & 10 \\
\hline Задоволений & 36 & 39,96 & 2 & 20 \\
\hline Не визначився & 7 & 7,77 & - & \\
\hline Незадоволений & 31 & 34,51 & 6 & 60 \\
\hline Максимально не задоволений & 8 & 8,88 & 1 & 10 \\
\hline Усього & $\mathbf{9 0}$ & $\mathbf{1 0 0}$ & $\mathbf{1 0}$ & $\mathbf{1 0 0}$ \\
\hline
\end{tabular}

Так, під час експрес опитування ми з'ясували, що думки респондентів суттєво розходяться. Узагальнений рівень позитивної відповіді (задоволеності) у студентів - 48,84\%, а негативної відповіді (незадоволений і не визначився) $51,16 \%$, що фактично дає змогу зробити висновок, що думки студентів 50 на $50 \%$ поділилися. Натомість, експерти відповіли, що задоволені - $30 \%$ опитаних і незадоволені - 70 \% відповідно. Такі відповіді експертів свідчать про рівень їх розуміння, з чим будуть зіштовхуватись майбутні випускники і до чого вони реально готові. На нашу думку, низький рівень реального оцінювання справ сформованості управлінської компетентності студентами зумовлений тим, що у студентів низький рівень особистої самокритичності через відсутність відповідних професійних знань.

Висновки та перспективи подальших досліджень. В подальшому під час нашого дисертаційного дослідження з'ясуємо педагогічні умови, що притаманні для нашого конкретного випадку підготовки саме фахівця ФКіС і спробуємо визначити критерії їі оцінювання.

\section{ЛІТЕРАТУРА}

1. Селевко Г. Компетентности и их классификация. Народное образование. 2004. № 4. C. $138-143$. 
2. Концепция модернизации российского образования на период до 2010 года. Москва : АПКиПРО, 2002. 24 с.

3. Словник української мови. URL : http://sum.in.ua/s/umova(дата звернення: 17.12.2019).

4. Великий тлумачний словник сучасної української мови / уклад. і голов. ред. В. Т. Бусел. Ірпінь : ВТФ «Перун», 2004. 1440 с.

5. Гапоненко Г. М. Організаційно-педагогічні умови формування професійної компетентності водолазів-підривників в ВВНЗ : дис. ... канд. пед. наук : 13.00.04. Хмельницький, 2014. 170 с.

6. Мішенко I. В. Управління як процес. URL : Ошибка! Недопустимый объект гиперссылки. (дата звернення: 17.12.2019).

7. Публічний електронний словник української мови. URL : http://ukrlit.org/slovnyk/slovnyk_ukrainskoi_movy (дата звернення: 17.12.2019).

8. Криштанович С. В. Формування управлінської компетентності фахівців фізичної культури і спорту. Науковий часопис НПУ імені М. П. Драгоманова. Київ : Випуск 64, 2018.C. 120-121

9. Дубревський Ю. М. Актуальність підготовки майбутніх фахівців фізичного виховання і спорту до формування управлінської компетентності. Педагогіка, психологія та медико-біологічні проблеми фізичного виховання і спорту. Донецьк. Випуск 09. 2012. URL: https://www.sportpedagogy.org.uа (дата звернення: 01.12.2019).

10. Войнар Ю., Наварецький Д., Глазирін І. Розвиток та сучасні тенденції системи підготовки фахівців з фізичної культури в умовах Свроінтеграції : монографія. Черкаси : Відлуння-Плюс, 2005. 184 с.

11. Шемчук В. А. Педагогічні умови розвитку управлінського мислення майбутніх магістрів військового управління в системі післядипломної освіти : дис. ... канд. пед. наук : 13.00.04. Київ, 2012. 288 с.

\section{REFERENCES}

1. Selevko, H. (2004) Kompetentnosty i ih klassyfykacyja. Narodnoe obrazovanye. № 4. S. 138-143 (of Ukraine).

2. Koncepcyja modernyzacyy rossyjskoho obrazovanyja na peryod do 2010 hoda. Moskva : APKyPRO, 2002. 24 s.

3. Slovnyk ukrajins'koji movy. [Electronic resource]. - Access mode : http://sum.in.ua/s/umova (of Ukraine).

4. Velykyj tlumačnyj slovnyk sučasnoji ukrajins'koji movy / uklad. i holov. red. V. T. Busel. Irpin' : VTF «Perun», 2004. 1440 s (of Ukraine).

5. Haponenko, H. M. Orhanizacijno-pedahohični umovy formuvannja profesijnoji kompetentnosti vodolaziv-pidryvnykiv v VVNZ: dys. ... kand. ped. nauk: 13.00.04. Xmel'nyc'kyj, 2014. $170 \mathrm{~s}$ (of Ukraine).

6. Mišenko, I. V. Upravlinnja jak proces. [Electronic resource]. - Access mode : https://www.pharmen cyclopedia.com.ua (data zvernennja: 17.12.2019), (of Ukraine).

7. Publičnyj elektronnyj slovnyk ukrajins'koji movy. [Electronic resource]. - Access mode : http://ukrlit.org/slovnyk/slovnyk_ukrainskoi_movy (data zvernennja: 17.12.2019), (of Ukraine).

8. Kryštanovyč S. V. (2018) Formuvannja upravlins'koji kompetentnosti faxivciv fizyčnoji kul'tury i sportu. Naukovyj časopys NPU imeni M. P. Drahomanova. Kyjiv : Vypusk 64, S. 120-121 (of Ukraine).

9. Dubrevs'kyj Ju. M. Aktual'nist' pidhotovky majbutnix faxivciv fizyčnoho vyxovannja i sportu do formuvannja upravlins'koji kompetentnosti. Pedahohika, psyxolohija ta medyko-biolohični problemy fizyčnoho vyxovannja i sportu. Donec'k. Vypusk 09. 2012. [Electronic resource]. - Access mode :https://www.sportpedagogy.org.ua (data zvernennja: 01.12.2019), (of Ukraine). 
10. Vojnar Ju., Navarec'kyj D., Hlazyrin I. (2005) Rozvytok ta sučasni tendenciji systemy pidhotovky faxivciv $\mathrm{z}$ fizyčnoji kul'tury $\mathrm{v}$ umovax Jevrointehraciji : monohrafija. Čerkasy : Vidlunnja-Pljus, $184 \mathrm{~s}$ (of Ukraine).

11. Shemchuk V. A. Pedahohichni umovy rozvytku upravlins'koho myslennya maybutnikh mahistriv viys'kovoho upravlinnya $\mathrm{v}$ systemi pislyadyplomnoyi osvity : dys. ... kand. ped. nauk : 13.00.04. Kyyiv, 2012. $288 \mathrm{~s}$ (of Ukraine).

РЕЗЮМЕ

Сергей Гапоненко,

магистр, аспирант

Каменец-Подольского Национального университета имени Ивана Огиенко,

\section{ФОРМИРОВАНИЕ УПРАВЛЕНЧЕСКОЙ КОМПЕТЕНТНОСТИ БУДУЩИХ УЧИТЕЛЕЙ ФИЗИЧЕСКОЙ КУЛЬТУРЫ}

В статье исследуются понятия «педагогические условия формирования», «управленческая компетентность спечиалистов физической культуры», а также выясняется современное состояние их сформированности. Проведен анализ и выяснено, что педагогические условия формирования - это необходимые и достаточные обстоятельства подготовки, обеспечивающче конечную иель. Анализ научных трудов специалистов позволяет сделать вывод, что будущуая деятельность специалиста физической культуры $и$ спорта, а фактически и управленческая компетентность предполагает, что во время профессиональной подготовки мы должны ее сформировать, что позволит более эффрективно использовать творческий, физический и интеллектуальный потенциал в нынешних условиях труда, выполняя профессиональные функции на фоне высокого уровня деловых и личностных качеств, в управлении процессами и людьми.

Ключевые слова: педагогические условия формирования, управленческая компетентность специилистов физической культуры.

\section{SUMMARI}

Serhii Haponenko, master, postgraduate of Kamenets-Podolsky National University named after Ivan Ohienko

\section{FORMATION OF MANAGEMENT COMPETENCE OF FUTURE TEACHERS OF PHYSICAL CULTURE}

Introduction. The global changes taking place in the world and in Ukraine in particular require the adaptation of modern society to the ephemerality of processes in all spheres of human activity. Instead, the higher education system is precisely that flexible, dynamic component that can greatly facilitate the ability of modern man to communicate in society. In this regard, the strategy of state personnel policy for 2012-2022 provides the provision of all spheres of life of the state with qualified personnel necessary for the realization of national interests in the context of Ukraine's development as a democratic, social state with a developed market economy.

Purpose. The purpose of the article is psychological and pedagogical analysis and substantiation of the concepts "pedagogical conditions of formation", "managerial competence of physical culture specialists", as well as clarification of the current state of their formation.

Аналіз наукових працьь фахівиів дозволяє зробити висновок, щзо майбутня діяльність фахівия фізичної культури і спорту, а фактично і управлінська компетентність передбачає, щзо під час професійної підготовки ми повинні ї̈ сформувати, щзо дозволить більш ефективно використовувати творчий, фізичний та інтелектуальний потенціал в 
теперішніх умовах праціі, виконуючи професійні функції на фоні високого рівня ділових $i$ особистісних якостей, в керуванні процесами та людьми.

Results. It is analyzed and clarified that the pedagogical conditions of formation are necessary and sufficient circumstances of training that provide the ultimate goal. Analysis of scientific works of specialists allows us to conclude that the future activities of a specialist in physical culture and sports, and in fact managerial competence implies that during professional training we must form it, which will more effectively use creative, physical and intellectual potential in current working conditions, performing professional functions on the background of a high level of business and personal qualities, in the management of processes and people.

Originality. Considering the works of these and many other scientists, we conclude that the managerial competence of specialists in physical culture is an integral indicator that includes: possession of modern pedagogical methods and technologies; communicativeness in combination with creative and prognostic thinking; comprehensive development; ability to analyze, generalize and implement of advanced modern foreign, domestic and historical sports experience; mastering the qualities that form the system of thinking, the speed of reaction to the problem and decisionmaking to eliminate it, or eliminate the consequences; ability to motivate those with whom classes are held, training to intensify their sports activities; ability to self-develop, self-improvement.

Conclusion. In the future, during our dissertation research, we will find out the pedagogical conditions that are inherent in our specific case of training a specialist of physical culture and sports and try to determine the criteria for its evaluation.

Key words: pedagogical conditions of formation, managerial competence of physical culture specialists. 